\title{
A Literature Review on the Relatiohship between Competition and Efficiency for Takaful and Conventional Insurance
}

\author{
Asif Ahmed, \\ Universiti Malaysia Sarawak, Sarawak, MALAYSIA \\ Rossazana Ab-Rahim \\ King Abdulaziz University, Jeddah, SAUDI ARABIA
}

Received: Nov. 20, 2021 Accepted: Dec. 20, 2021 Online published: Dec. 27, 2021

doi:10.5296/jpag.v11i4.19394

URL: https://doi.org/10.5296/jpag.v11i4.19394

\begin{abstract}
When there are many players operate in a particular market, it encourages competition. Thus, healthy competition in the market leads to efficiency performance. Takaful and conventional insurance are the two parallel methods used to transact insurance business. The emergence of the Takaful market has contributed to competitiveness and conventional insurance is facing competition with Takaful. Therefore, this paper attempts to review the literatures relating to the relationship between competition and efficiency between Takaful and conventional and whether there exist a positive or a negative relationship.
\end{abstract}

\section{Introduction}

The insurance industry makes an important contribution in the development and prosperity of the socio-economics of the society and this normally achieved as a result of minimizing the risk of all economic activities (Lee, 2019). Insurance is a social protection system and there are two ways in which this social protection system being offered, namely, Takaful and conventional insurance.

Takaful method is defined to provide a guarantee to the members to support in the event of any mishaps that causes financial loss. Principally, the Takaful system is based on concept of mutual co-operation, sharing responsibility, guaranteeing, protection, and assistance among the participants (Fadun, 2014). Members pool their financial resources together against certain loss exposures (Maysami \& Kwon, 1999). The concept of Takaful is based on mutual cooperation among the participants, but, more importantly, it complies with all the 
principles of Sharia'h law (Mazahir et al., 2018). These principles are participants co-operate among themselves for their common good. Secondly, participants pay contribution (tabarru) to assist those that required help; thirdly, division of losses and liabilities spread across the community through pooling system; fourthly, uncertainty eliminated in respect of the contribution (tabaru) and compensation; and the last principle is that the system of Takaful should not derive advantage at the cost of others. Takaful is an Islamic Sharia'h Compliant method where surpluses returned to the participants after meeting the liabilities.

The main reason for the emergence of Takaful is that conventional insurance does not fulfill the requirements of Sharia'h law. Features, such as uncertainty (gharar), gambling (maisar), and usury (riba). Saaty and Ansari (2008) pointed out that gharar, maisar, and riba have been the major reasons for opposing the conventional insurance. These factors changed the essence of the simple practice of mutual help of risk sharing to one that led to causing doubt among Muslims about its compliance with the Sharia'h law (Salman \& Htay, 2013).

There are various models of Takaful insurance. These are generally categorized into five; namely, mudarabah, musyarakah, wakalah, waqf, and ju'alah (Frenz \& Soualhi, 2010; Salman et al., 2019). However, the two most common models used by Takaful companies are the mudharabah and wakalah model. Some firms are established based on hybrid system, which means that mudarabah and wakalah models combine to form a hybrid model. In this model, the relationship between the operators combines not only the role of the businessperson or mudarib but also that of the wakeel of the participant. Under Takaful, all investments made into Sharia'h compliant areas. Under Takaful system the distribution of profit is done according to pre-agreed ratios. Surplus and loss is shared from the pool jointly (Merdad et al., 2015).

Takaful was formerly introduced in 1979 in Sudan, and from there onwards Takaful has progressed quite steadily both in terms of demographic expansion and business volume that estimated to be about 33USD billion (Rahman, 2013). According to Al-Amri (2015), the most concentrated market in terms of Takaful business is Saudi Arabia and Malaysia. According to Ang (2020), Middle East performing reasonably well in respect of Takaful with $63 \%$ global market share, followed by Southeast Asia with 30\%. There are certain regions, such as Africa and others, which are adopting Takaful as a new method of insurance.

The other method that used to transact insurance is conventional insurance. The primary purpose of the conventional insurance is the social security of the members participating in the risk sharing mechanism. Pfeffer \& Klock (1974) suggested the definition of conventional insurance as the 'risk transfer mechanism where the risk transferred from insured to insurer'. This characterization of insurance highlights a major aspect that can be found more or less in most other definitions, namely, the reduction of risk through some transfer mechanism (Al-Salih \& Holloway, 2014). Therefore, a risk transfer mechanism is essential for the arrangement of insurance.

Conventional insurance has been there since the industrial revolution in the 16th century when the need to protect the business assets arose (Abdou et al., 2014). It began in the early $16^{\text {th }}$ century with the great fire of London in which 13,000 houses were burnt to ashes 
(Rawlings, 2016). The incident led to the development of conventional insurance. Most of the insurance companies appeared between the seventeenth and nineteenth century, and their development grew rapidly, especially in France for instance, with the establishment of Compagnie Assurances Generals in 1753. Similarly, in 1710, a firm was established called the Sun Fire which is a British based company. The USA also took steps in 1752 by establishing the Mutual Relief Association and the Insurance Corporation in 1772 being the very first insurance company in Philadelphia (Al-Salih \& Holloway, 2014). The Dutch who colonized the region for more than 350 years brought insurance to Indonesia. Accordingly, insurance and its respective institution was officially included in the agenda of Indonesia law in 1848. Hence, Indonesia also promulgated the legalization of Dutch Trading Laws.

Conventional insurance, besides providing protection to the participating members, also caters for the profitability for the owners. Conventional insurance traditionally operated by insurance formed mostly as ownership by individual or multiple investors or shareholders. When a company makes a profit, the owner retains the profit. In modern times, the conventional insurance companies formed based on joint stock companies. The founding shareholders and the purchasers of the share stocks share the profit earned.

However, over the years, conventional insurance has been more commercially oriented at the cost of the participating members' contributions. If conventional insurance makes a business surplus the major portion is held by the owners of the surplus, but when it incurs losses, the losses are passed on to the members through higher future contributions. Conventional insurance however has managed to hold the major market share (Alajaji et al., 2017).

\section{Literature Review}

Competition has risen manifold in the insurance sector due to the fact that number of insurance firms have increased due to the Takaful mushrooming (Alshammari et. al. 2019). Alshammari in his studies analyzed the effects of competition with regard to the cost efficiency of Takaful and conventional insurance for the period from 2009 to 2016. He used stochastic frontier cost function. His findings suggest that there is a positive relationship between competition and efficiency and that it supports the Quiet Life hypothesis. His findings further highlighted that in a weaker competitive environment manager may use their firms market power and could minimize their efforts. The author observed that there exist significant differences between conventional and Takaful and that the relationship between competition and efficiency results positive for Takaful whereas it is negative in respect of the conventional insurance.

Khandwalla (1973) carry out the study to analyse the relationship among the three categories of competition and their overall evaluation. The author analysed 96 manufacturing companies and the multiple dimensional effects of the control of top management in these companies. The statistics shows that competition positively effects control. Among the three categories of competition, the product competition all alone has a substantial positive effect with respect to all the management control variables.

Liu (2018) highlighted that when there is an intense product competition in the market then this 
may affect the firm performance. The author further highlighted that if the firms have better practices for corporate governance then it neutralizes the negative effect of intense product competition on the firm's performances. The author further highlighted that connection between higher and lower product market, competition performance shows a weaker result in respect of the firms controlled by state owned enterprises when it is compared to non-state-owned enterprises.

Alhassan (2016) studied the relationship between competition and efficiency. The study measured the technical and cost efficiency results by DEA analysis wherein the Boone indicator used as an alternative to competition. To measure the panel regression, model the factors of lending, fixed effects, tangibility, allowance, profitability and limiting the bank size used. In the study, the growth convergence theory applied to evaluate the presence of efficiency convergence.

Bakour and Gallali (2013) made a comparative analysis of the Islamic and conventional banks associated with MENA region, which although not related to insurance, it is very much relevant to the finance sector. The author study was span over the period of 2004 to 2013, using the modelling econometric panel data. To highlight the degree of competition in MENA region, the author used sample of 66 Islamic banks and 157 conventional banks. The author measured the degree of efficiency of banks using stochastic frontier analysis. The author indicated that there is a positive effect between efficiency and competition when the level of efficiency on the level of competition is evaluated.

Noman at al. (2017) evaluated the effects of competition on the financial soundness and stability of the financial sectors dealing in commercial areas. The period considered in this range was from 1990 to 2014. The measures of competition used were Panzar-Rosse H-statistic, Lerner index, and Herfindahl-Hirschman Index. The conclusion facilitates the non-linear relationship when it comes to the competition and financial integrity of the banking industry and financial sectors.

Albaity M., \& et al., (2019) the author studied competition with regard to bank stability. The study was based with regard to MENA region. The topic studied was the moderating effect of conventional banking versus Islamic banking. The findings highlighted that competition-fragility is rather significant for Islamic banks than compare to the conventional ones.

Akhter et al., (2017) finds that GDP and capita have negative effect with regard to the demand of conventional and Islamic insurance. Although Islamic insurance reflects significant resistance to survive against the crises.

Abel et. al., (2020) the author highlighted that competition is a crucial factor in insurance sector and that it is an essential ingredient since it leads to the minimization of uncertainty and risk. Further, it results in better allocation of the resources, improves products and bring innovation, and overall improves economic growth and facilitate efficient production of financial services. The author analyses the effects of competition in Zimbabwe during the period 2010-2017. First, he indicated that competition in Zimbabwe's insurance industry was 
moderate. Based on the outcome author suggested that government ensure conducive macroeconomics environment for the businesses to have better competitiveness. The economy should avoid to have hyperinflationary situation which otherwise negatively impacts the insurance purchasers as well as insurance firms.

Alshammari et al., (2019) nexus between the competition and efficiency of conventional and Takaful insurance measured by employing Granger Causality test using input and output.

$$
\begin{array}{ll}
\text { Eff }_{\text {it }}=\alpha_{i}+\beta_{1} \operatorname{Com}_{i t}+\beta_{2} \operatorname{Cont}_{i t}+\varepsilon_{i t} & \text { Equation 1 } \\
\operatorname{Com}_{i t}=\alpha_{i}+\beta_{1} \text { Eff fit }_{\text {it }}+\beta_{2} \operatorname{Cont}_{i t}+\varepsilon_{i t} & \text { Equation 2 }
\end{array}
$$

The first equation (Equation 1) examines the effects of competition and the macroeconomics variable towards efficiency and the second equation (Equation 2) examines the impact of efficiency and macroeconomics towards competition. Where for insurance firms $i$ denotes time $t$ denotes yearly observations, $E f f_{i t}$ is either of the efficiency indicators technical efficiency, pure technical efficiency, scale efficiency, allocative efficiency and cost efficiency. $\mathrm{Com}_{i t}$ is Lerner Index score. cont $_{i t}$ signify the macroeconomic control variables.

Egbunike (2018) the author finds that factors like macroeconomics are those factors that are outside the firms and that these outside factors are not under the control of management. These factors are environmental, political, social, suppliers, competitors and statutory regulations. Moreover, these are significant economic factors such as unemployment, stock market index, consumer price index, gross domestic product and interest rate (Broadstock et al., 2011). Also, these important macroeconomic indicators have reflected unpredicted results as it embodies fluctuations. This has especially witnessed when the countries come out from recession. As an instance, the inflation rate measured by the CPI is presently at double-digit level in respect of the Middle East market. It is also important to note with regard to macroeconomics factors like GDP and CPI that these are the factors that are true reflection of the country's financial health. These macroeconomics factors are widely considered fundamental indicators of macroeconomic performance. The overall size of the economy can be estimated through the GDP. Where the GDP of a country is high means that it has positive impact on the efficiency results of the industry. Therefore, GDP taken into account as one of the determinants of macroeconomics. Secondly, CPI taken as second determinant being a crucial indicator for many financial analysts. This due to the that of its substantial and deep effect on firms and asset performance.

Stokes \& Purdon (2017) granger causality test as author mentioned is a statistical method to investigate the information that flows between time series. The Granger causality tests are used for various types of efficiency. These efficiencies are technical efficiency (TE), pure technical efficiency (PTE), scale efficiency (SE), cost efficiency (CE), and allocative 
efficiency (AE). The granger casualty test is performed in order to examine the relationship between efficiency and competition within the GCC insurance industry. To proceed with the Granger Causality test, the first step is the selection of an appropriate lag length. Therefore, the lag length selection carried out, which suggests by Akaike information criterion (AIC). Hence, by choosing an appropriate lag, the model selection test AIC has been conducted.

Berger \& DeYoung (1997) the standard procedure for testing whether the financial sector, like bank efficiency Granger causing competition that includes evaluating the following equations via least-squares regression:

$$
\begin{array}{ll}
y_{i t}=\alpha_{0} \sum_{I=1}^{m} \alpha_{1}^{y} y_{i t-1}+\sum_{I=1}^{m} \delta_{1}^{y} x_{i t-1}+f_{i}^{y}+u_{i t}^{y} & \text { Equation 3 } \\
x_{i t}=\beta_{0} \sum_{I=1}^{m} \alpha_{1}^{x} x_{i t-1}+\sum_{I=1}^{m} \delta_{1}^{y} y_{i t-1}+f_{i}^{*}+u_{i t}^{x} & \text { Equation 4 }
\end{array}
$$

Where $y$ denotes efficiency, $x$ denotes the competition, and $f$ indicates the bank's individual effect $i$ and $t$ denotes the indices for the bank and the time period, respectively. Each dependent variable is regressed on its yearly lags and on those of the other variable. The aim of this study is to explore whether the variable $y_{i}$ Granger-causes variable $y_{j}$, by employing a testing to see whether the history of the other entire $y_{s}$ or a number of control variables, are added to all equations. If the coefficients of the $x$ lags are substantially different statistically, from 0 , then $x$ assist to forecast or Granger-cause $y$. Granger-causality gives association of the past history, in which a change in one variable precedes a change in the other but does not necessarily imply economic causation.

\section{Conclusion}

Bakour and Gallali (2013) predicts the level of efficiency on the level of competition. Results suggest a positive effect between these two variables. Alshamrani et. al., (2019) the relationship between competition and efficiency is positive and supports the Quiet Life (QL) hypothesis. Bansal et. al. (2019) the study supports the "Quiet Life" hypothesis, higher competition leading to higher GCC insurance companies' efficiency.

Abel et. al., (2020) and Alshammari et. al., (2019) lower competition improve scale efficiency and vice versa. Since Takaful market is emerging market, competition serve important and significant role in term of scale efficiency of the market. Scale efficiency indicates that insurances firms are using input at an optimal scale and while on reducing input without affecting the output level. According to Abel et. al., (2020) lower market power reflects highly competitive market leads to high level of scale efficiency by diversifying product and services, reduction in risk and uncertainty, enables efficient resources allocation, enhances product innovation and lower moral hazard. Besides that, competition improve the efficiency of the financial sector in terms of specialisation, adopting lending technologies, reducing the cost of processing, lowering banks' credit risk and better screen borrowers (Andrieş \& Căpraru, 2014; Dick \& Lehnert, 2010; Zarutskie, 2013). However, for the 
macroeconomic variables; GDP is positively related to technical efficiency and pure technical efficiency at $1 \%$ and $10 \%$ significance, respectively.

The positive relationship between competition and cost efficiency may encourage policy makers and regulators to support a competitive insurance industry, which should improve efficiency. However, they should be aware of the degree of competition and use restrictions and requirement for market entry carefully.

The important theory is that competition on a standalone basis is not necessarily a single aspect for an insurance industry's successful performance. Therefore, the emergence of other aspects, such as the regulatory supervision of the insurance industry, play an important role in terms of competition (Klein, 2008).

The literature review suggest that competition has a significant relationship with the performance of the insurance firms. The condition of the performance of the insurance firms suggested a positive relationship between competition and efficiency, which illustrates that competition, improves the efficiency of the insurance firms in terms of utilizing the resources. Moreover, a negative relationship explains that competition hinders the efficiency because firms are maximizing the profit, and delight in monopolizing the market.

\section{References}

Abdou, H., Ali, K., \& Lister, R. J. (2014). A comparative study of Takaful and conventional insurance: Empirical evidence from the Malaysian market. Insurance Markets and Companies: Analyses and Actuarial Computations, 5(1), 22-34.

Abel, C., Afach, S., Ayres, N. J., Baker, C. A., Ban, G., Bison, G., Bodek, K., Bondar, V., Burghoff, M., Chanel, E., \& Chowdhuri, Z. (2020). Measurement of the permanent electric dipole moment of the neutron. Physical review letters, 124(8), p.081803. https://doi.org/10.1103/PhysRevLett.124.081803

Akhter, W., \& Vasileios, P., \& Khan, S. U. (2017). A comparison of Islamic and conventional insurance demand: Worldwide Evidence during the Global Financial Crisis, Research in International Business and Finance, Elsevier, 42(C), 1401-1412. https://doi.org/10.1016/j.ribaf.2017.07.079

Alajaji, K., Hassan, A. A. M., Ismail, F., Jaffer, S., Tan, Y. Y., \& Lindsay, U. (2017). Global Takaful Report 2017: Market trends in family and general Takaful. Milliman Research Report. (pp. 1-56).

Al-Amri, K. (2015). Takaful insurance efficiency in the GCC countries. Humanomics, 31(3), 344-353. https://doi.org/10.1108/H-05-2014-0039

Albaity, M., Mallek, R. S., \& Noman, A. H. Md. (2019). Competition and bank stability in the MENA region: The moderating effect of Islamic versus conventional banks. Emerging Markets Review, 38, 310-325. https://doi.org/10.1016/j.ememar.2019.01.003

Alhassan, A. L., \& Biekpe, N. (2016). Competition and efficiency in the non-life insurance market in South Africa. Journal of Economic Studies, 43(6), 882-909. 
https://doi.org/10.1108/JES-07-2015-0128

Al-Salih, A., \& Holloway, R. (2014). Takaful and conventional general Insurance: Analysing Muslim consumers' perception and choices in the UK and Saudi Arabia. Royal Holloway, University of London.

Alshammari, A. A., Syed Jaafar Alhabshi, S. M. bin, \& Saiti, B. (2019a). The impact of competition on cost efficiency of insurance and takaful sectors: Evidence from GCC markets based on the Stochastic Frontier Analysis. Research in International Business and Finance, 47, 410-427. https://doi.org/10.1016/j.ribaf.2018.09.003

Andrieş, A. M., \& Căpraru, B. (2014). The nexus between competition and efficiency: The European banking industries experience. International Business Review, 23(3), 566-579. https://doi.org/10.1016/j.ibusrev.2013.09.004

Ang, C. (2020). MENA markets back on growth path. Middle East Insurance Review (MEIR).

Bakour, A., \& Gallali, M. I. (2013). Competition and Efficiency: Comparative Analysis between Islamic and Conventional Banks of MENA Region. International Journal of Business and Commerce, 5(3), 20-40.

Bansal, R., \& Singh, D. (2019). Efficiency drivers of insurers in GCC: An analysis incorporating company-specific and external environmental variables. Cogent Economics \& Finance, 9(1), 1922179. https://doi.org/10.1080/23322039.2021.1922179

Berger, A. N., \& DeYoung, R. (1997). Problem loans and cost efficiency in commercial banks. Journal of Banking \& Finance, 21(6), 849-870. https://doi.org/10.1016/S0378-4266(97)00003-4

Broadstock, D. C., Collins, A., \& Hunt, L. C. (2011). Transportation oil demand, consumer preferences and asymmetric prices", Journal of Economic Studies, 38(5), 528-536. https://doi.org/10.1108/01443581111161797

Dick, A. A., \& Lehnert, A. (2010). Personal bankruptcy and credit market competition. The Journal of Finance, 65(2), 655-686. https://doi.org/10.1111/j.1540-6261.2009.01547.x

Egbunike, C. F., \& Okerekeoti, C. U. (2018). Macroeconomic factors, firm characteristics and financial performance: A study of selected quoted manufacturing firms in Nigeria. Asian Journal of Accounting Research, 3(2), 142-168. https://doi.org/10.1108/AJAR-09-2018-0029

Fadun, O. S. (2014). Takaful (Islamic insurance) practices: Challenges and prospects in Nigeria. Journal of Insurance Law \& Practice, 4(2), 12-28.

Frenz, T., \& Soualhi, Y. (2010). Takaful and Re-Takaful: Principles and practices. Islamic Banking and Finance Institute, Malaysia (IBFIM), ISBN 9789834377793.

Khandwalla, P. N. (1973). Effect of Competition on the Structure of Top Management Control. Academy of Management Journal, 16(2), 285-295. https://doi.org/10.2307/255329

Klein, R. W. (2008). An overview of the insurance industry and its regulation. Center for Risk 
Management \& Insurance Regulation, Georgia State University.

Lee, H. (2019). Insurance Development and Economic Growth. Financial Statistical Journal, 1(2), 1-17. https://doi.org/10.24294/fsj.v1i4.1057

Liu, L., Wen, Q., \& Haman, J. (2018). Product market competition, state-ownership, corporate governance and firm performance. Asian Review of Accounting, Emerald Group Publishing, 26(1), 62-83. https://doi.org/10.1108/ARA-05-2017-0080

Maysami, R. C., \& Kwon, W. J. (1999). An Analysis of Islamic Takaful Insurance. Journal of Insurance Regulation, 18(1), 109-133.

Mazahir, S. M. M., Ab Rahman, A., \& Ramzy, M. I. (2018). An analysis on Takaful operation under conventional regulator: A Sri Lankan experience. KATHA-The Official Journal of the Centre for Civilisational Dialogue, 13(1), 54-72. https://doi.org/10.22452/KATHA.vol13no1.3

Merdad, H. J., Kabir Hassan, M., \& Hippler, W. J. (2015). The Islamic risk factor in expected stock returns: An empirical study in Saudi Arabia. Pacific-Basin Finance Journal, 34(C), 293-314. https://doi.org/10.1016/j.pacfin.2015.04.001

Noman, A. H. M., Gee C.S., \& Isa C.R. (2017). Does competition improve financial stability of the banking sector in ASEAN countries? An empirical analysis. Journal Plos One, 12(5), e0176546. https://doi.org/10.1371/journal.pone.0176546

Pfeffer, I., \& Klock, D. R. (1974). Managing climate risk: extreme weather events and the future of insurance in a climate-changed world. Australasian Journal of Environmental Management, 2011 Prentice-Hall.

Rahman, M. A. (2013). Comparative study on the efficiency of Bangladeshi conventional and Islamic life insurance industry: A non-parametric approach. Asian Business Review, 2(3), 88-99. https://doi.org/10.18034/abr.v3i2.91

Rawlings, P. (2016). The Great Fire of London and the Origins of Fire Insurance: A Brief Note. Queen Mary School of Law Legal Studies Research Paper, 246.

Saaty, A. S., \& Ansari, Z. A. (2008). Takaful - An Islamic Way of Insurance: Developments, Growth, Challenges and Issues. King Abdulaziz University.

Salman, S. A., \& Htay, S. N. N. (2013). Nomination and Hibah issues in Malaysian Takaful (Islamic insurance) industry. International Journal of Multidisciplinary Research, 1(12), 5-8.

Salman, S. A., Hassan, R., \& Tahniyath, M. (2019). Takaful an Innovation to Contemporary Insurance. International Journal of Research in Social Sciences, 9(8), 434-442.

Stokes, P. A., \& Purdon, P.L. (2017). A study of problems encountered in Granger causality analysis from a neuroscience perspective. Proceedings of the National Academy of Science of the United State of America. https://doi.org/10.1073/pnas.1704663114

Zarutskie, R. (2013). Competition, financial innovation and commercial bank loan portfolios. 


\section{Macrothink}

Journal of Public Administration and Governance ISSN 2161-7104

Journal of Financial Intermediation, 22(3), 373-396.

https://doi.org/10.1016/j.jfi.2013.02.001

\section{Copyright Disclaimer}

Copyright for this article is retained by the author(s), with first publication rights granted to the journal.

This is an open-access article distributed under the terms and conditions of the Creative Commons Attribution license (http://creativecommons.org/licenses/by/4.0/). 